DOI https://doi.org/10.15407/usim.2019.06.058

UDC 004.896

SUKHORUCHKINA O.N., Senior researches, Research and Training Centre of Information Technologies and Systems of the NAS and MES of Ukraine,

Acad. Glushkov ave., 40, Kiev, 03187 , Ukraine,

sukhoru@gmail.com

\title{
THE VIRTUAL SENSORS FOR IYTELLIGENT CONTROL OF THE MOBILE ROBOT
}

The completeness of situational awareness has an important significance for intelligent control of autonomous mobile robot when it is operated at dynamic environment. Usually the robot is equipped with some set of physical sensors for evaluating certain environmental properties. However, the information from physical devices only may not be enough at analyzing situations to select targeted robot actions. The technique of some virtual sensors implementations for estimations of possible mutual "robot - surrounding objects" states which necessary for path planning problem or planning the robot's target positions are considered.

Keywords: autonomous mobile robot, intelligent control, virtual sensor, 3D model.

\section{Introduction}

The mobile robots that are able to autonomously carry out a specific class of the missions at the dynamic environment are in demand in various fields of human activity. The practical implementation of intelligent control techniques for the technical systems with similar properties are being actively developed [1-3].

The multi-functional robots that are able to autonomously achieve user-defined target states in undefined or partial defined surroundings are of most interest. Such robotic system when it operations at partial determinacy conditions should be able to independently perceive the environment and form sequence of task-oriented actions allow for current mutual states «robot - environment». In this case the completeness of situational awareness has an important significance for selection and activating by robot control system the adequate actions from the available set of its behavior algorithms.

The intelligent control system (ICS) of an autonomous mobile robot (MR) should not only be situational aware of the current robot states in environment, but also predict the possible states. As the sources of current awareness are the aggregate of hardware in the form of sensors for perceiving certain environment properties and software implementations for the interpretation of the data received from them. The ability of ICS MR to form its own representation of surrounding and the robot state in it is an essential property of the autonomous intelligent systems.

A wide range of sensors - the devices for signals registration of certain physical modality, can be used as information providers on the actual environment features for MR. As a rule, modern sensors are microprocessor-based devices with primary signal processing and generation of output data in digital formats. MR can be equipped with video cameras, rangefinders of various types, thermal imagers or modern devices for direct forming 3D environment models. The sensors for evaluating any specific environmental characteristics can also be used.

The motion control issues - where and how the robot can and should move, largely depend on the 
relative positions of the MR and surrounding objects. However, the information only from physical devices may not be enough at analyzing situations by control system to select and activate targeted MR actions. So, the physical devices data characterize the current position of the MR and surrounding objects, while the decision on next MR actions requires an estimation of the predicted states in which the MR will be as a result of these actions. In addition, for some aspects of the situations analysis, there are no physical devices as providers of the necessary information.

The estimates of the actual states of the pair "MR, environment" are formed on the current data from onboard physical sensors, when external objects directly surrounding the MR during its movement are found in the zones of their perception. However, each type of physical sensors has a limited perception zone with data reliability sufficient for MR control tasks. The computer models of environment representing in ICS memory and real time simulations of MR functional interaction with surroundings provide substantial assistance in generating missing information and must compensate the actual situations uncertainty outside these zones.

Based on these software tools, a number of virtual sensors as software modules that generates relevant structured information when analyzing the mutual states of 3D models of MR and surroundings objects can be implemented. In some cases, the virtual sensors are able to replace expensive physical sensor devices or to generate data that, in principle, cannot be registered with physical devices.

The virtual sensors presented in this work, using a dynamically edited model of the robot's external environment, which is based on information about the real world from available physical sources, generate the predicted characteristics of possible mutual states of the "MR, environment" pair, which are necessary for the autonomous control system to select appropriate robot actions. Samples of virtual sensors used by ICS MR ERIC developed at the International Research and Training Center of the National Academy of Sciences of Ukraine and the Ministry of Education and Science of Ukraine are shown $[4,5]$. These software tools as the sources of information about potential events and MR states are important primarily in the tasks of choosing the allowable MR paths and positions that satisfy certain target conditions.

\section{Problem definition}

The MR environment in our case is the premises with initially unknown or partially known location of the objects, the visual features and geometric parameters of some of them are already at the robot ICS knowledge base. The surface of the MR motion is a horizontal plane. The key role in the perception of surrounding objects is played by rangefinder sensors and video camera installed on the MR functioning prototype. Technologies for analyzing and interpreting the information of these devices are shown in [5-7].

The MR ICS is the control system with informational feedbacks, the organization principle of which in the case under consideration is shown in $[4,5]$. The expected informational equivalent of the robot action result is formed by mathematical modeling and represents the expected mutual state of the pair "MR, environment" in the special memory structures.

The spatial-geometrical and visual characteristics of surrounding objects are functionally important. The $3 \mathrm{D}$ models of environment objects including the robot model are represented by the sets of nonintersecting convex polyhedrons, which approximate the connected piecewise-homogeneous spatial domains occupied by these objects with some accuracy [8]. In specialized ICS permanent memory structures, the representation of the spatial geometry of objects is supplemented by their inherent attributes - the visual properties of the objects surfaces, namely, the dominant colour components and image feature descriptors of these objects. For example, the SIFT (Scale-Invariant Feature Transform) algorithm can be used for formation of the sets of descriptors characterizing the object visual features [9].

The formation of the $3 \mathrm{D}$ models of the MR environment in real time is provided by software implementation of algorithms for analysis of current sensory information and object recognition. 

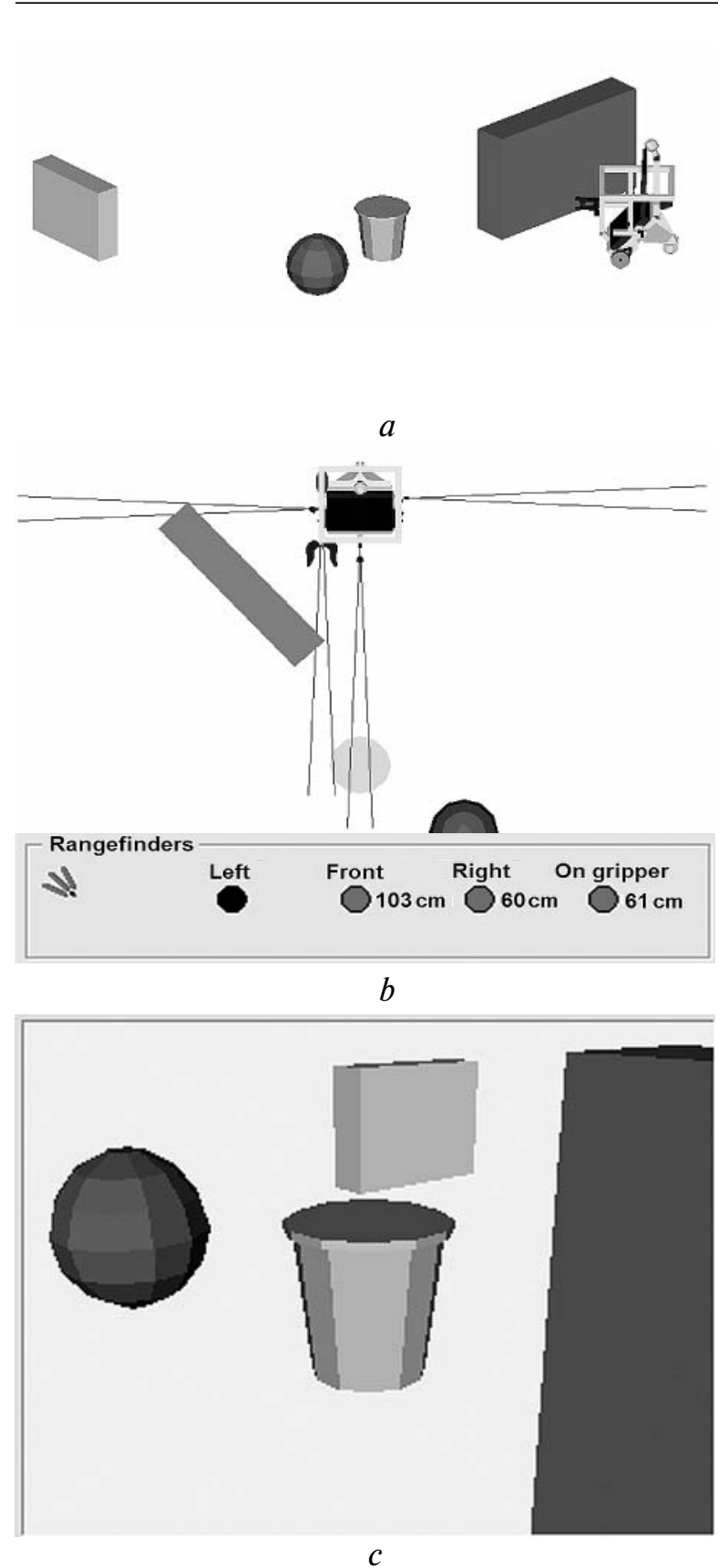

Fig. 1. The results of 3D simulation

In addition to these models, the basic tools for implementation of ICS virtual sensors are software resources for simulating in spatial virtual environment the MR functional activities such as the robot motion and environmental perception by onboard rangefinders and video camera. Fig. 1 shows significant fragments of the simulation results, namely:

- an arbitrary view of the MR operating space model with current robot position (Fig. 1, a);

- the model of object perceptions by rangefinders (Fig. 1, b);

- the shot model of the MR operating space by the robot camera model (Fig. 1,c), when the robot located as in Fig. 1, $a$.

The rangefinder model generates the results of distance measurements between the rangefinder receiver and the object surfaces that fall into the sensor sensitivity zone, and the video camera model generates the images of the environment model when the MP model is in a certain position. These processes mathematical models are based on the recursive algorithm for determining intersections of convex polyhedrons and the methods of projective geometry.

The software presented in the work as virtual sensors, using specified above resources, generate model estimates of the following characteristics:

- the presence of obstacles in the near zone of the MR maneuvering;

- the presence of obstacles along the MR path, planned to the target position in the form of a broken line;

- the objects that can fall into the robot camera field of view when MR is located at a certain position.

The unified structures of mathematical representation of the models of MR environment objects and the robot functional components allow MR ICS to effectively generate the necessary information at solving these problems.

\section{The virtual sensor for safety motion verification}

Safety motion verification should be preceded by any MR maneuvers in the environment. Of course, in a dynamic environment, only the data of physical sensors recording the actual current MR state in a real environment can be considered reliable. However, free space estimation based on the current rangefinders data is possible only within their sensitivity zones, and according to the results of the analysis of onboard camera images - in the zone of reliable visual recognition of objects. In this ap- 
proach to the ICS organization, the monitoring of the correspondence of the actual environment sensory perception to the expected information equivalent of the MR action results is constantly active [5]. Detection of the state of the so-called sensory discomfort leads to automatic activation of MR actions to clarify the situation and the corresponding correction of the environment model. All the virtual sensors presented in the work are implemented taking into account this property of the ICS.

One of the computationally intensive but important tasks is identification of the obstacle collisions threat when the robot path planning. Actually, the algorithm for the robot path planning to target state with obstacles avoidance is not considered here.

However, the estimates of the obstacles free path are based on the computational procedure of a virtual sensor for safety motion verification. It generates information on the obstacles presence or absence in the spatial area within which the planned trajectory is located.

Let us consider two types of feasible MR motion paths:

- maneuvering in the near area of the current MR location;

- motion along a lengthy trajectory in the polyline form.

The first motion type is typical for kinematic scheme of two-wheel MR, when during the robot rotation around its vertical axis only its orientation changes. Short robot linear motions of forward or backward also belong to this type if their lengths and lengths of areas near robot platform, where there is no perception of physical sensors, are comparable. The presence of such "dead areas" is associated with location of sensors relative to the robot platform either with own characteristics of certain sensors. The second MR motion paths type arises at motion planning to predetermined target position located in the environment model outside the areas of efficient perception of the actual surroundings by physical sensors.

A preliminary estimate of MR free maneuvering area both in a small neighborhood around robot platform and along each of linear sections of the lengthy motion path can be obtained using simplified 3D models of such areas as sequences of con-
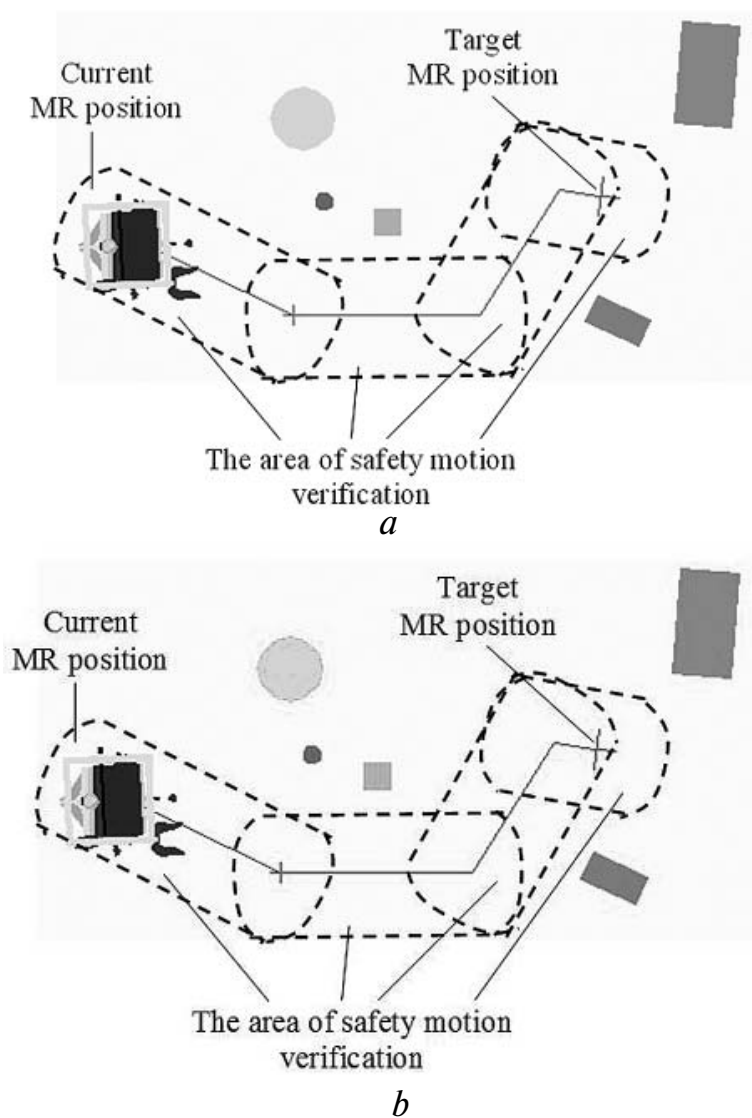

Fig. 2. The sensitivity areas of virtual sensor for safety motion verification

vex polyhedrons, inside which the robot motion is supposed.

Checking the intersections of such convex polyhedrons with of environment object models which are also represented by the sets of convex polyhedrons is the main computing task of a virtual sensor for verification of MR safety motion. In our case, these calculations are based on the recursive algorithm for determining the minimum distance between convex polyhedrons [10]. The output of this sensor is a list of objects, whose 3D models have at least one common point with the specified sets of convex polyhedrons as $3 \mathrm{D}$ model of the MR motion area from current position to the planned target one. The absence of the objects in the list indicates the possibility of safe MR motion of along the selected path. Fig. 2 schematically shows the sensitivity areas of this virtual sensor. Fig. 2, $a$ represents the first stage of planning a safe MR path from cur- 


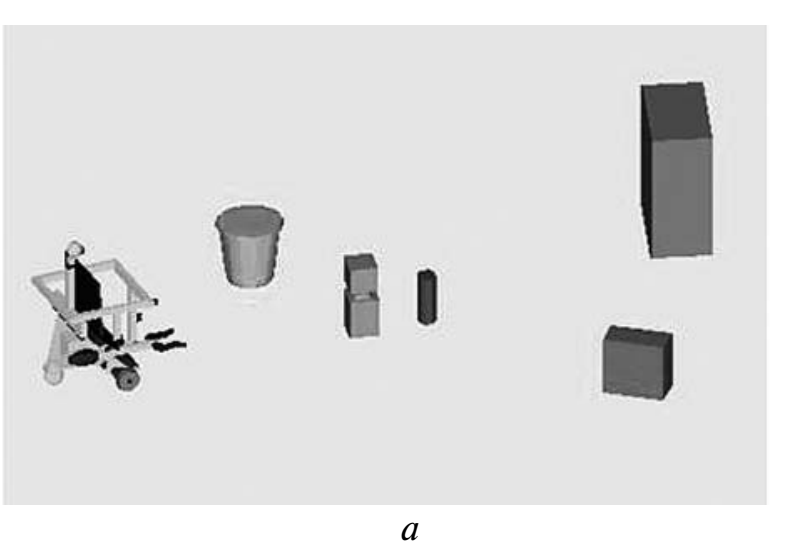

Fig. 3. Simulation of the onboard camera field of view

rent position to the predetermined target one based on the environment model, when according to the virtual sensor generated data several obstacles are detected on the MR path. In Fig. 2, $b$ the final plan of the safe robot motion with obstacles absence in each trajectory linear section and in the robot's rotation areas is shown.

\section{The virtual sensor for camera field of view verification}

Some mission successful completion by the autonomous service robot equipped with video camera and object recognition software depends on the ability of the ICS to determine previously in what location should be MR in order for objects of its functional interest to be in the onboard camera field of view. The virtual sensor with the output as a list of surroundings model objects that will fall into the camera field of view, when the MR model is in the defined location, has been implemented for this. This software sensor can predict what objects the onboard camera would see if the robot moves to given location.

As shown above (see Fig. 1, c), the software ICS resources for each MR location in the environment model synthesizes the shot model of onboard camera. Such preliminary field of view verification makes it possible to select from the set of possible MR locations such target robot positions in which the real camera shot will image specific objects or environment area of interest. Fig. 3, $a$ shows an arbitrary viewpoint of 3D environment model and

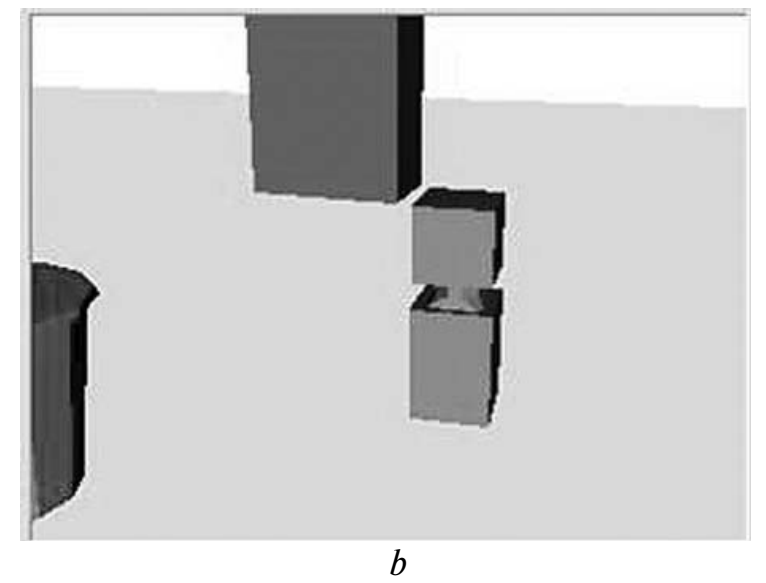

the MR model in it, and Fig. 3, $b$ - the shot model of onboard camera corresponding to a given MR position relative to objects. According to the output of this virtual sensor, not all objects in front of the robot fall into the camera field of view and can be imaged on shot of real onboard camera when the MR takes the certain location. The computing resources of this sensor also verify the possible overlap of some object models by others on the camera shot due to the shape, size and spatial location of this objects.

Fig. 4 shows the result of using this virtual sensor in the task of selecting such MR positions from which the target object will fall into the camera's field of view. Namely, Fig. 4, $a$ shows the set of planned robot locations satisfying such goal, and Fig. $4, b$ is the shot model of onboard camera when $\mathrm{MR}$ is in one of the appropriate positions.

Thus, the considered virtual sensors generate structured information in goal-directed mutual analysis of 3D models of the robot and surrounding objects. Such information cannot be obtained from physical sensors for environment perception from the current MR location, and its absence significantly complicates the ICS abilities to successfully select robot path for safe moving and certain target MR positions from a variety of potentially acceptable ones.

\section{Conclusions}

A mobile robot, as a moving technical system, needs, first of all, to identify the spatial characteri- 

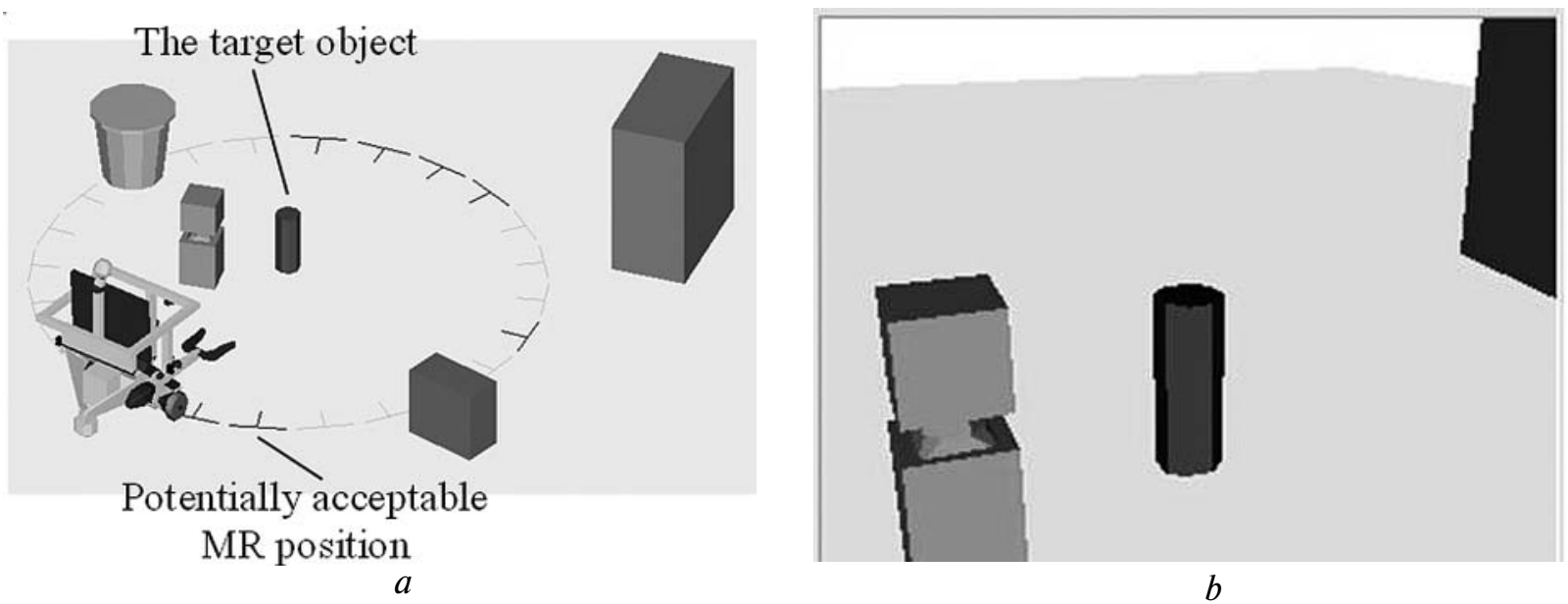

Fig. 4. The choice of target MR positions on the virtual sensor information

stics of surrounding objects for safe and effective autonomous functioning. Fulfillment by the robot of missions to search, pursue or move certain objects requires its ability to form the object models and recognize both the obstacles and target ones for the corresponding mission.

The proposed approaches to implementation and use of virtual sensors significantly complement the abilities of the intelligent MR control system to analyze the sets of potentially permissible mu- tual states of a moving system with surrounding objects.

Such analysis is impossible if robot control system uses only current information from physical sensors. The virtual sensors allow expanding the analyzed set of robot states to activate its adequate purposeful behaviors, and the ability of an artificial system to represent its state in the certain spatial locations is an important characteristic of intellectuality.

\section{REFERENCES}

1. Makarov, I.M., Lokhin, V.M., Manko, S.V., Romanov, M.P., 2006. "Artificial Intelligence and Intelligent Control Systems". M .: Nauka, $333 \mathrm{p}$.

2. Zhdanov, A.A., 2008. "Avtonomnyy iskusstvennyy intellekt". M.: Binom. Laboratoriya znaniy, 359 p.

3. Chechkin, A.V., 1998. "Printsipy i metody matematicheskogo modelirovaniya intellektual'nykh sistem", Intellektualnyye sistemy, 3, Vyp. 1-2, pp. 63-83.

4. Sukhoruchkina, O.N., 2007. "The structures of functional organization of the mobile cybernetic system intelligent control”.Upravlausie sistemy i masiny, 3, pp. 26-33, 63. (In Russian).

5. Sukhoruchkina, O.N., 2012. "The structures and information processes of the mobile robot intelligent control". Zbirnyk naukovykh prats Instytutu problem modelyuvannya v energetytsi im. G.Ye. Pukhova NAN Ukrainy, No. 62, pp. 93-101.

6. Sukhoruchkina, O.N., 2008. "The multifunctional application of 3D models in the autonomous mobile robot dataware". Collected Abstracts of the 19th All-Russian Scientific-and-Technological Conference with International Participation, April 8-9, Saint-Petersburg, pp. 107-108.

7. Sukhoruchkina, O.N., Progonnyi, N.V., Voronov, M.A., 2017. "Interpretation and use of measurements of the rangefinder sensor in the control tasks of the autonomous robot". Upravlausie sistemy i masiny, 1, pp. 26-34. (In Russian).

8. Pronin, A.S., Progonny, N.V., Sukhoruchkina, O.N., 1991. "Construction of images of three-dimensional scenes formed by disjoint convex polyhedra". Problem solving in intelligent computer environments. Kiev: Institute of Cybernetics named after V.M. Glushkov Academy of Sciences of the Ukrainian SSR, pp. 46-55. (In Russian). 
9. Lowe, D.G., 1999. "Object recognition from local scale-invariant features". Proceedings of the International Conference on Computer Vision (Corfu, Greece, September 1999), No. 2, 1150-1157. DOI: 1109/ICCV.1999.790410.

10. Pronin A.S., 1987. "Rekursivnyy algoritm opredeleniya minimal'nogo rasstoyaniya mezhdu vypuklymi mnogogrannikami”. 16 p. Dep. v VINITI 04.09.87, № 6502 I87.

Received 04.12.19

\section{ЛІТЕРАТУРА}

1. Макаров, И.М., Лохин, В.М., Манько, С.В., Романов, М.П., 2006. Искусственный интеллект и интеллектуальные системы управления. М.: Наука, 333 с.

2. Жданов, А.А., 2008. Автономный искусственный интеллект. М.: Бином. Лаборатория знаний, 359 с.

3. Чечкин, А.В., 1998. Принципы и методы математического моделирования интеллектуальных систем, Интеллектуальные системы, 3, Вып. 1-2, С. 63-83.

4. Сухоручкина О.Н. Структуры функциональной организации интеллектуализированного управления мобильной связью. УСиМ, 3, 2007, С. 26-33, 63.

5. Sukhoruchkina, O.N., 2012. The structures and information processes of the mobile robot intelligent control. Zbirnyk naukovykh prats Instytutu problem modelyuvannya $\mathrm{v}$ energetytsi im. G.Ye. Pukhova NAN Ukrainy, No. 62, pp. 93-101.

6. Sukhoruchkina, O.N., 2008. The multifunctional application of 3D models in the autonomous mobile robot dataware. Collected Abstracts of the 19th All-Russian scientific-and-technological conference with International participation "Extreme Robotics", April 8-9, Saint-Petersburg, pp. 107-108.

7. Sukhoruchkina, O.N., Progonnyi, N.V., 2018. On the formation of the object models by autonomous mobile robot resources. Upravlausie sistemy i masiny, № 6, C. 36-45. DOI: https://doi.org/10.15407/usim.2018.06.036

8. Пронин, А.С., Прогонный, Н.В., Сухоручкина, О.Н., 1991. Построение изображений объемных сцен, образованных непересекающимися выпуклыми многогранниками. Решение задач в интеллектуальных компьютерных средах. Киев: Ин-т кибернетики им. В.М. Глушкова АН УССР. С. 46-55.

9. Lowe, D.G., 1999. Object recognition from local scale-invariant features. Proceedings of the International Conference on Computer Vision (Corfu, Greece, September 1999), No. 2, 1150-1157. DOI: 10.1109/ICCV.1999.790410

10. Пронин, А.С., 1987. Рекурсивный алгоритм определения минимального расстояния между выпуклыми многогранниками. 16 с. Деп. в ВИНИТИ 04.09.87, № 6502 И87.

Надійшла 04.12.2019

O.М. Сухоручкіна, старший науковий співробітник

Міжнародний науково-навчальний центр інформаційних технологій та систем НАН та

МОН України, просп. Академіка Глушкова, 40, м. Київ, 03187, Україна,

sukhoru@gmail.com,

\section{ВІРТУАЛЬНІ СЕНСОРИ ДЛЯ ІНТЕЛЕКТУАЛЬНОГО УПРАВЛІННЯ МОБІЛЬНИМ РОБОТОМ}

Вступ. Повнота ситуаційної обізнаності має важливе значення для інтелектуального управління автономним мобільним роботом (МР), коли він працює в динамічному середовищі. Зазвичай МР оснащений деяким набором фізичних сенсорів для оцінки певних властивостей оточення. Однак інформації лише від фізичних пристроїв може бути недостатньо для аналізу ситуацій, для вибору цільових дій робота. Розглянуто підходи до реалізації деяких віртуальних сенсорів для оцінки можливих взаємних станів “робот - оточуючі об'єкти”, які необхідні для задачі планування маршруту або планування цільових положень МР.

Мета статті - представлення підходів до реалізації декількох типів віртуальних сенсорів для оцінки взаємних положень МР і об’єктів оточення, які необхідні в задачах планування цілеспрямованих дій робота системою інтелектуального управління. Спираючись на оцінки віртуальних сенсорів можна обрати безпечні траєкторії руху або такі положення у просторі, що є допустимими та відповідають певним умовам.

Методи. Представлені підходи спираються на використання просторових моделей об'єктів та моделювання сприйняття оточення бортовою відеокамерою МР. Геометричні моделі об’єктів базуються на представленні їх сукупностями опуклих багатогранників. Використовується рекурсивний алгоритм оцінки взаємних положень моделей об'єктів. Сприйняття оточення відеокамерою робота моделюється за правилами проективної геометрії. 
Результат. Запропоновані віртуальні сенсори використано як базові модулі алгоритмів оцінки взаємних положень робота і оточуючих об'єктів в програмних ресурсах системи інтелектуального управління діючим прототипом MP ERIC, що забезпечує можливість автономного виконання роботом складних завдань користувача у недетермінованому динамічному середовищі.

Висновки. Запропоновані підходи до реалізації та використання віртуальних сенсорів суттєво доповнюють можливості інтелектуальної системи управляння МР аналізувати множини потенційно допустимих взаємних станів рухомої системи з оточуючими об'єктами. Такі оцінки принципово неможливі з використанням лише поточної інформації фізичних сенсорів. Здатність штучної системи уявити свій стан у певних просторових положеннях $є$ важливою характеристикою образного мислення. Віртуальні сенсори вказаного типу дозволяють формувати множини можливих станів робота, які відповідають цільовим вимогам, і обирати безпечні траєкторії руху до них.

Ключові слова: автономний мобільний робот, інтелектуальне управління, віртуальний сенсор, 3D-модель.

О.Н Сухоручкина, старший научный сотрудник,

Международный научно-учебный центр информационных технологий и систем НАН

и МОН Украины, просп. Акад. Глушкова, 40, Киев, 03187, Украина,

sukhoru@gmail.com,

\section{ВИРТУАЛЬНЫЕ СЕНСОРЫ ДЛЯ ИНТЕЛЛЕКТУАЛЬНОГО УПРАВЛЕІНИЯ МОБІЛЬНЫМ РОБОТОМ}

Введение. Для интеллектуального управления автономным мобильным роботом (МР) в динамической среде важное значение имеет полнота ситуационной осведомленности. Обычно робот оснащен некоторым набором физических датчиков для оценки определенных свойств окружающей среды. Однако информации только от физических устройств может быть недостаточно при анализе ситуаций для выбора целевых действий робота. Рассмотрены подходы к реализации некоторых виртуальных сенсоров для оценки возможных взаимных состояний “робот - окружающие объекты”, которые необходимы для задачи планирования маршрута или планирования целевых положений МР.

Цель статьи - представление подходов к реализации нескольких типов виртуальных сенсоров для оценки взаимных положений МР и объектов окружения, которые необходимы в задачах планирования целенаправленных действий робота системой интеллектуального управления. Опираясь на оценки виртуальных сенсоров можно выбрать безопасные траектории движения или такие положения в пространстве, которые являются допустимыми и соответствуют определенным условиям.

Методы. Представленные подходы опираются на использование пространственных моделей объектов и моделирование восприятия окружения бортовой видеокамерой МР. Геометрические модели объектов базируются на представлении их совокупностями выпуклых многогранников. Используется рекурсивный алгоритм оценки взаимных положений моделей объектов. Восприятие окружения видеокамерой робота моделируется по правилам проективной геометрии

Результат. Предложенные виртуальные сенсоры использованы как базовые модули алгоритмов оценки взаимных положений работа и окружающих объектов в программных ресурсах системы интеллектуального управления действующего прототипа $M P$ ERIC, что обеспечивает возможность автономного выполнения роботом сложных задач пользователя в недетерминированной динамической среде.

Выводы. Предложенные подходы к реализации и использованию виртуальныхсенсоров существеннодополняют возможности интеллектуальной системы управления МР анализировать множества потенциально допустимых взаимных состояний подвижной системы с окружающими объектами. Такие оценки принципиально невозможны с использованием только текущей информации физических сенсоров. Способность искусственной системы представить свое состояние в определенных пространственных положениях является важной характеристикой образного мышления. Виртуальные сенсоры указанного типа позволяют формировать множества возможных состояний робота, соответствующих целевым требованиям и выбирать безопасные траектории движения к ним.

Ключевые слова: автономный мобильный робот, интеллектуальное управление, виртуальный сенсор, $3 D$-модель. 